\title{
Effects of physical activity on body composition of children
}

\author{
Ana Nikolic \\ Faculty of Sport and Physical Education, University of Nis, Nis, Serbia.
}

\begin{abstract}
Body composition is the composition of a human organism represented by the size and grouping of the existing measurable segments of which it is made. The aim of this review is to determine the effects of physical activity on body composition of children, based on collected and analysed study. Descriptive method and theoretical analysis have been used for collection, classification and analysis of the targeted study. The study was collected by searching electronic databases of scientific data. The case study includes 20 closely related studies. In all of them, except in one study within this review, the authors have come to the conclusion that physical activity has statistically significant positive effects on body composition of children.
\end{abstract}

Keywords. Body composition, children, exercise, physical activity.

\section{Introduction}

$\mathrm{C}$ lassification of people by type of constitution was recorded even in the era of the Hippocrates. Nowadays, the relationship between body constitution and physical activity is a burning issue and an extremely complex problem (Medved, 1980).

Body composition is the composition of a human organism represented by the size and grouping of existing measurable segments of which it is composed (Ugraković, 2001).

Important precondition for healthy and quality growing is the optimal body structure, especially in children of the younger school age. Obesity is a phenomenon caused by the imbalance in intake and consumption of calories. Disturbed balance of body structure can lead to discord in growth and development, slowing down the foundation of all abilities (motor, intellectual, social, etc.) (Syakaly 2008).
There is a trend of increased number of overweight and obese people in developed countries, and that obesity occurs in all the younger age categories (Horvat et al., 2009). The state of childhood nutrition can have lifelong effects in terms of general health, physical activity and productivity in the workplace. Body composition is an important aspect of human growth, maturation and aging, and has a wide range of health implications.

\section{Methods}

Descriptive method and theoretical analysis have been used for collection, classification and analysis of the targeted study. The studies were collected by searching electronic databases of scientific data. Also, the papers were collected from the references of previously found, fully accessible papers on this and similar topics. A number of papers was collected by searching the printed scientific conference proceedings in the library of the Faculty of Sport and Physical Education in Niš. Additional literature in the form of textbooks has also been used. The key words used in the search engines were: Physical activity, Exercise, Body composition, Children.

The reasearch was based on works published in the period from 2008 to 2018.

\section{Results}

Case study includes 20 closely related studies, chronologically listed in Table 1.

The study of Aries et al. (Aries et al., 2008) was carried out in order to determine the correlation between physical activity and body composition, BMI, as well as fitness ability. The sample of 
respondents consisted of 288 boys and 347 girls aged 14 to 17 who were divided into two experimental groups. After the study, the authors concluded that physically active children have less BMI and better fitness abilities.

Simon and associates (Simon et al., 2008) conducted a designed study on 954 high school pupils of both sexes in order to determine the effects of a designed physical exercise program within physical education classes. The entire treatment lasted four school years. The subject of the study was body composition. The results showed that there is statistically significant improvement in monitored parameters in favour of the experimental group.

\section{Table 1}

Chronological table of the collected and analysed studies.

\begin{tabular}{|c|c|c|c|c|c|c|c|}
\hline \multirow[b]{2}{*}{ Reference } & \multicolumn{3}{|c|}{ Sample respondent } & \multicolumn{3}{|c|}{ Experimental treatment } & \multirow[b]{2}{*}{ Results } \\
\hline & $\mathrm{n}$ & Age & Gender & Group & $\begin{array}{l}\text { Exercise } \\
\text { program / } \\
\text { duration }\end{array}$ & $\begin{array}{c}\text { Tracked } \\
\text { parameters }\end{array}$ & \\
\hline $\begin{array}{l}\text { Aries et al., } \\
2008\end{array}$ & $\begin{array}{l}288 \mathrm{~m} \\
347 \mathrm{f}\end{array}$ & $\begin{array}{l}14-17 \\
\text { years }\end{array}$ & $\mathrm{M} / \mathrm{F}$ & $2 \mathrm{E}$ & $\begin{array}{c}6 \text { tests from } \\
\text { Fitnessgram test } \\
\text { battery to assess } \\
\text { BMI and fitness } \\
\text { capabilities }\end{array}$ & $\begin{array}{l}\text { BMI; fitness } \\
\text { capabilities }\end{array}$ & $\begin{array}{l}\text { Physically active children } \\
\text { have less BMI and better } \\
\text { fitness capabilities }\end{array}$ \\
\hline $\begin{array}{c}\text { Simon et al., } \\
2008\end{array}$ & 954 & $\begin{array}{l}\text { high } \\
\text { school } \\
\text { pupils }\end{array}$ & $\mathrm{M} / \mathrm{F}$ & $1 \mathrm{E} 1 \mathrm{~K}$ & $\begin{array}{l}4 \text { years of special } \\
\text { physical exercise } \\
\text { program within } \\
\text { physical } \\
\text { education classes } \\
\text { in eight high } \\
\text { schools in France }\end{array}$ & $\begin{array}{c}\text { Body } \\
\text { composition, } \\
\text { BMI }\end{array}$ & $\begin{array}{l}\text { Statistically significant } \\
\text { improvement of } \\
\text { monitored parameters in } \\
\text { favour of the } \\
\text { experimental group }\end{array}$ \\
\hline $\begin{array}{c}\text { Farias et al., } \\
2009\end{array}$ & 383 & 15 years & $\mathrm{M} / \mathrm{F}$ & $1 \mathrm{E} 1 \mathrm{~K}$ & $\begin{array}{l}68 \text { classes of } \\
\text { physical activity } \\
\text { (aerobics, } \\
\text { flexibility } \\
\text { exercises, rope } \\
\text { skipping, } \\
\text { walking, } \\
\text { running, } \\
\text { jumping in the } \\
\text { same rhythm, } \\
\text { recreational } \\
\text { games) lasting } 60 \\
\text { minutes during } \\
\text { one school year. }\end{array}$ & $\begin{array}{l}\text { Body } \\
\text { composition, } \\
\text { BMI fat } \\
\text { percentage, } \\
\text { flexibility }\end{array}$ & $\begin{array}{l}\text { The treatment influenced } \\
\text { the improvement of all } \\
\text { monitored parameters for } \\
\text { the respondents from the } \\
\text { experimental group }\end{array}$ \\
\hline $\begin{array}{l}\text { Evans et al., } \\
2009\end{array}$ & 68 & 14 years & F & $\begin{array}{l}1 \mathrm{E} \\
1 \mathrm{~K}\end{array}$ & $\begin{array}{l}6 \text { months of } \\
\text { aerobics } \\
\text { program }\end{array}$ & $\begin{array}{l}\text { Body } \\
\text { composition, } \\
\text { BMI fat } \\
\text { percentage }\end{array}$ & $\begin{array}{l}\text { The applied experimental } \\
\text { treatment resulted in } \\
\text { decrease of BMI, as well } \\
\text { as fat percentage in the } \\
\text { bodies of the respondents } \\
\text { from the experimental } \\
\text { group }\end{array}$ \\
\hline $\begin{array}{c}\text { Tse et al., } \\
2009\end{array}$ & 203 & $\begin{array}{l}\text { high } \\
\text { school } \\
\text { pupils }\end{array}$ & $\mathrm{M} / \mathrm{F}$ & $1 \mathrm{E}$ & $\begin{array}{l}3 \text { months of } \\
\text { increased } \\
\text { physical activity } \\
\text { with diet } \\
\text { regulation }\end{array}$ & $\begin{array}{c}\text { Body } \\
\text { composition }\end{array}$ & $\begin{array}{l}\text { Positive influence of the } \\
\text { three-month treatment on } \\
\text { body composition has } \\
\text { been noted }\end{array}$ \\
\hline
\end{tabular}


Table 1. (Continued)

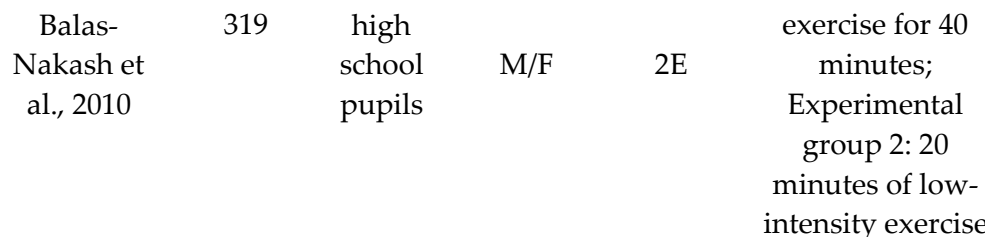

$\begin{array}{cccccc}\begin{array}{l}\text { Velez et al., } \\ 2010\end{array} & 28 & \begin{array}{c}\text { high } \\ \text { school } \\ \text { pupils }\end{array}\end{array} \quad \mathrm{M} / \mathrm{F} \quad 1 \mathrm{E} \quad 1 \mathrm{~K} \quad \begin{gathered}12 \text { weeks of } \\ \text { fitness training }\end{gathered}$

$\begin{array}{cccccc}\begin{array}{c}\text { Burguera et } \\ \text { al., 2011 }\end{array} \quad 870 & \begin{array}{c}\text { high } \\ \text { school } \\ \text { pupils }\end{array}\end{array} \quad$ M/F $\quad$ 1E $\quad \begin{gathered}6 \text { months of } \\ \text { additional } \\ \text { exercise sessions }\end{gathered}$

\begin{tabular}{|c|c|c|c|c|c|}
\hline $\begin{array}{l}\text { Hardy et al., } \\
2011\end{array}$ & 18 & $\begin{array}{l}15-16 \\
\text { years }\end{array}$ & $\mathrm{F}$ & $1 \mathrm{E}$ & $\begin{array}{l}\text { times a week for } \\
\quad 45 \mathrm{~min} ; \\
\text { Week 6-13 - } 4 \\
\text { times a week for } \\
\text { 60min. }\end{array}$ \\
\hline
\end{tabular}

$\begin{array}{cccccc}\text { Grave et al., } & 1050 & \text { high } & & & \\ 2012 & \mathrm{~m} & \begin{array}{c}\text { school } \\ \text { pupils }\end{array} & \mathrm{M} / \mathrm{F} & 2 \mathrm{E} & \text { NR program }\end{array}$

Song et al. 22

$14-16$ 2012

$\begin{array}{lcc}\text { Stanimirov } & 250 \mathrm{~m} & 16-17 \\ \text { et al., } 2012 & 136 \mathrm{f} & \text { years }\end{array}$

$\mathrm{M} / \mathrm{F}$

Meucci et al., 2013
22

$\begin{array}{cc}\text { high } & \\ \text { school } & \mathrm{M} / \mathrm{F}\end{array}$

$\mathrm{E}$
12 weeks of aerobic program, 3 times a week for 50 minutes

BMI was measured with anthropometry, while the level of physical activity was measured using the questionnaire

4 weeks of aerobics during summer break
BMI; body fat percentage

Significant influence of performed treatment on body composition

Gradual increase in exercise intensity resulted in statistically significant improvement in body composition, BMI, and influenced the reduction in fat percentage in respondents

Statistically significant

BMI; fat percentage, aerobic fitness influence of applied program on physical components of high school pupils

Statistically significant improvement of monitored parameters in favour of the experimental group

Statistically significant lower values of monitored parameters were observed in respondents who were physically more active

Body Significant improvement composition, of monitored parameters

cardiovascular in favour of the endurance experimental group 


\begin{tabular}{|c|c|c|c|c|c|c|c|}
\hline \multicolumn{8}{|c|}{ Table 1. (Continued) } \\
\hline $\begin{array}{c}\text { Calceterra et } \\
\text { al., } 2013\end{array}$ & 22 & 15 years & $\mathrm{M} / \mathrm{F}$ & $1 \mathrm{E}$ & $\begin{array}{l}12 \text { weeks of } \\
\text { circular working } \\
\text { method } \\
\text { (aerobics, power } \\
\text { training and } \\
\text { combination of } \\
\text { football, rugby, } \\
\text { volleyball and } \\
\text { basketball) }\end{array}$ & $\begin{array}{c}\text { Body } \\
\text { composition, } \\
\text { cardiovascular } \\
\text { endurance }\end{array}$ & $\begin{array}{l}\text { Statistically significant } \\
\text { differences in BMI } \\
\text { reduction were observed. } \\
\text { The program has } \\
\text { positively influenced } \\
\text { upon the second } \\
\text { monitored parameter as } \\
\text { well }\end{array}$ \\
\hline $\begin{array}{l}\text { Rezek et al., } \\
2013\end{array}$ & $\begin{array}{c}19 \mathrm{~m} \\
9 \mathrm{f}\end{array}$ & $\begin{array}{l}\text { high } \\
\text { school } \\
\text { pupils }\end{array}$ & $\mathrm{M} / \mathrm{F}$ & $1 \mathrm{E}$ & $\begin{array}{c}8 \text { weeks of } \\
\text { special physical } \\
\text { exercise program } \\
\text { with reduced } \\
\text { nutrition on the } \\
\text { principle of } 500 \\
\text { calories per day }\end{array}$ & $\begin{array}{c}\text { Body } \\
\text { composition, } \\
\text { amount of fat, } \\
\text { aerobic fitness }\end{array}$ & $\begin{array}{l}\text { Body mass in boys } \\
\text { decreased by } 11.4 \% \text {, in } \\
\text { girls } 11.0 \% \text {; the amount of } \\
\text { fat decreased by } 23.8 \% \text { in } \\
\text { boys and } 21.5 \% \text { in girls }\end{array}$ \\
\hline $\begin{array}{l}\text { Singh et al., } \\
\quad 2014\end{array}$ & 80 & $\begin{array}{l}14-16 \\
\text { years }\end{array}$ & M & $1 \mathrm{E} 1 \mathrm{~K}$ & $\begin{array}{l}\text { Pilates training } \\
\text { (45 minutes per } \\
\text { day, } 3 \text { days a } \\
\text { week). Total } \\
\text { duration of the } \\
\text { program: } 12 \\
\text { weeks. }\end{array}$ & $\begin{array}{c}\text { Body } \\
\text { composition } \\
\text { (fat quantity and } \\
\text { fat without } \\
\text { mass) }\end{array}$ & $\begin{array}{l}\text { Statistically significant } \\
\text { results in favour of the } \\
\text { experimental group after } \\
\text { performed experimental } \\
\text { treatment }\end{array}$ \\
\hline $\begin{array}{l}\text { Cruz et al., } \\
2014\end{array}$ & 50 & $\begin{array}{c}15 \\
\text { years }\end{array}$ & M & $1 \mathrm{E} 1 \mathrm{~K}$ & $\begin{array}{l}\text { Pilates program } \\
2 \text { times a week, } \\
\text { seven exercises } \\
\text { at a time, } 2-3 \\
\text { series, } 15 \text { to } 20 \\
\text { repetitions with } \\
45 \text { seconds } \\
\text { break. Total } \\
\text { duration of the } \\
\text { program: } 6 \\
\text { weeks }\end{array}$ & $\begin{array}{c}\text { Body } \\
\text { composition, fat } \\
\text { percentage, } \\
\text { flexibility, } \\
\text { muscle strength }\end{array}$ & $\begin{array}{c}\text { Conducted experimental } \\
\text { treatment did not result } \\
\text { in statistically significant } \\
\text { changes in monitored } \\
\text { parameters }\end{array}$ \\
\hline $\begin{array}{l}\text { Guo et al., } \\
2017\end{array}$ & 227 & $\begin{array}{c}3-5 \\
\text { years }\end{array}$ & $\mathrm{M} / \mathrm{F}$ & $1 \mathrm{E}$ & $\begin{array}{c}\text { Children's } \\
\text { Activity and } \\
\text { Movement } \\
\text { exercise program }\end{array}$ & $\begin{array}{c}\text { Body } \\
\text { composition, } \\
\text { BMI, motor skills }\end{array}$ & $\begin{array}{l}\text { Statistically significant } \\
\text { positive correlation } \\
\text { between physical exercise } \\
\text { and BMI reduction in } \\
\text { children }\end{array}$ \\
\hline $\begin{array}{l}\text { Jones et al., } \\
2018\end{array}$ & 450 & $\begin{array}{c}\text { 9-11 } \\
\text { years }\end{array}$ & $\mathrm{M} / \mathrm{F}$ & $1 \mathrm{E}$ & $\begin{array}{l}\text { Assessment of } \\
\text { total daily } \\
\text { activity with } \\
\text { accelerometer }\end{array}$ & $\begin{array}{c}\text { Body } \\
\text { composition, } \\
\text { BMI, } \\
\text { cardiorespiratory } \\
\text { fitness }\end{array}$ & $\begin{array}{l}\text { The researchers } \\
\text { concluded that physical } \\
\text { activity over a longer } \\
\text { period of time has } \\
\text { statistically significant } \\
\text { positive changes in terms } \\
\text { of the monitored } \\
\text { parameters }\end{array}$ \\
\hline $\begin{array}{l}\text { Sallis et al., } \\
\quad 2018\end{array}$ & 928 & $\begin{array}{l}12-16 \\
\text { years }\end{array}$ & $\mathrm{M} / \mathrm{F}$ & $1 \mathrm{E}$ & $\begin{array}{c}\text { Walking } \\
\text { monitored by an } \\
\text { accelerometer / } 7 \\
\text { days }\end{array}$ & $\begin{array}{c}\text { Body } \\
\text { composition, } \\
\text { BMI }\end{array}$ & $\begin{array}{l}\text { Statistically significant } \\
\text { positive correlation } \\
\text { between physical activity } \\
\text { - walking to the } \\
\text { monitored parameter of } \\
\text { the respondents }\end{array}$ \\
\hline
\end{tabular}

Farias and his associates (Farias et al., 2009) carried out a study with the sample of 383 subjects of both sexes, and observed the effects of 68 hours of aerobics, exercise, flexibility, walking, running, jumping in the same rhythm, recreational games) on body composition - BMI, percentage of fat, as well as 
flexibility. It lasted 60 minutes during one school year. The treatment affected the improvement of all monitored parameters upon the respondents who were in the experimental group.

Evans et al. (2009) determined the effects of a sixmonth aerobics program on the body composition BMI and fat percentage. The sample of respondents included 68 girls, 14 years of age. The applied experimental treatment resulted in BMI decrease, as well as the percentage of body fat of the respondents in the experimental group.

Another study was concerned with determining the effects of physical activity on the body composition. Namely, Tse and associates (Tse et al., 2009) applied a three-month program of enhanced physical activity with the regulation of nutrition for 203 high school pupils. After the experimental treatment and re-measurement, a positive influence of the three-month treatment on body composition was observed.

Balas-Nakash et al. (2010) aimed to determine how the 12-week aerobics program affects body composition in a total of 319 high school pupils of both sexes. The sample was divided into two experimental groups, with one experimental group conducting aerobic training for 40 minutes, while the second group conducted a twelve-minute lowintensity exercise program in the same period. The results obtained by the authors showed statistically significant positive effect on the body composition in the first experimental group.

Velez et al. (2010) were focused on determining the effects of a 12-week fitness program on body composition and strength. The sample of respondents consisted of 28 high school pupils divided into one experimental and one control group. The results that the authors of this study came to pointed out to a statistically significant progress in the experimental parameters in relation to the control group.

Burguera et al. (2011) had the goal to examine in their study whether six months of additional exercise sessions, apart from regular physical education classes, had effects on BMI and the percentage of body fat. The sample of respondents in their survey consisted of 870 high school pupils of both sexes who made up one experimental group. After the final measurement and detailed analysis of the obtained results, a significant influence of the performed treatment on the body composition was established.
Hardy et al. (2011), as many authors before them, had a goal to examine whether a particular physical exercise program, applied in the appropriate time period, had positive effects on body composition, BMI or percentage of fat. The sample of respondents - 18 girls, 15-16 years of age were an experimental group that was subject to a specially designed program for a total duration of 13 weeks. The authors designed their program so that from the first to the fifth week they practiced twice for 45 minutes, and from sixth to thirteenth week four times a week for 60 minutes. The program developed in such manner resulted in statistically significant improvement in body composition, BMI, and influenced the reduction in fat percentage in respondents.

Grave et al. (2012) had a large sample of respondents consisting of 1050 boys and 1448 girls and they determined the effects of the NR program on BMI, fat percentage and aerobic fitness. The whole sample of respondents was divided into two experimental groups. Statistically significant influence of the applied program on the physical components of high school pupils was determined.

Song et al. (2012) also conducted a study in which they aimed to determine the effects of a 12-day aerobic program on body composition and cardiovascular endurance. The study included 22 boys aged 14 to 16 who were divided into one experimental and one control group. After obtaining the results, statistically significant improvement was determined in the monitored parameters in favour of the experimental group.

Researchers from the region (Stanimirov et al., 2012) measured BMI as well as the index of bodyweight by means of anthropometry, while the level of physical activity was measured using a questionnaire. They aimed to determine the correlation between physical activity and body composition on a sample of 250 boys and 136 girls, 16 to 17 years of age. Statistically significant lower values of monitored parameters were observed in respondents who were physically more active.

In the study Meucci et al. (2013), a four-week aerobic program was implemented during the summer break with the aim of determining how such program would affect body composition and cardiovascular endurance. Respondents who participated in this study were high school pupils, divided into one experimental and one control group. After the applied program, repeated measurement and analysis of the obtained results, 
significant improvement of monitored parameters in favour of the experimental group was established.

Calceterra et al. (2013) used a sample of 22 respondents, of both sexes, 15 years of age, and applied specially designed circular working method (aerobics, power training and a combination of football, rugby, volleyball and basketball) for a total duration of 12 weeks. The observed parameters in this study were body composition and cardiovascular endurance. Statistically significant differences in BMI reduction were observed. The program positively influenced the second monitored parameter as well.

Researchers (Rezek et al., 2013) applied an eightweek program of special physical exercise program with reduced calorie diet of 500 calories per day on a sample of 19 boys and 9 girls in order to determine whether the applied program will have effects on body composition, amount of fat and aerobic fitness. Body mass in boys decreased by $11.4 \%$, in girls $11.0 \%$; the amount of fat decreased by $23.8 \%$ in boys and $21.5 \%$ in girls.

In their study, Singh et al. 2014) had 80 boys, 14 to 16 years of age, who completed Pilates training (45 minutes a day, three times a week) for a total duration of 12 weeks in order to determine the effect of the program on body composition. Statistically significant results were recorded in favour of the experimental group after the experimental treatment was carried out.

Cruz et al. (2014) had the goal of examining the effects of six-week Pilates program on body composition, fat percentage, flexibility and muscle strength of 50 boys, 15 years of age. The program was conducted twice a week and consisted of seven exercises, 2 to 3 series of 15 to 20 repetitions and 45 seconds of pause. The experimental treatment developed in such a manner did not result in statistically significant changes in monitored parameters.

Guo et al. (2017), in their research on 227 boys and girls, 3-5 years of age, used specially designed Children's Activity and Movement exercise program in order to determine whether and in what way it would have the effect on body composition and motor skills. Statistically significant positive correlation between physical exercise and BMI reduction in children was recorded.

Recent researches have been carried out to determine the correlation between physical activity and body composition of children. Namely, in a study by Jones et al. 2018, on the sample of 450 children, of both sexes, 9 to 11 years of age, the level of physical activity has been determined by using the accelerometer. The researchers concluded that physical activity over a longer period of time has statistically significant positive change in terms of monitored parameters. The same results came from the authors Sallis et al. 2018. Their study was designed in the same way, with the difference that their study involved a larger number of respondents $(n=928)$.

\section{Discussion}

The effects of certain physical activity on body composition of children is a problem that is presently being dealt with by an increasing number of scientists around the world. Bearing in mind that modern age and technological development has resulted in the emergence of hypokinesia and, consequently, many side effects of this modern-day illness, the popularity of this topic is justified among the researchers. In addition to the theoretical contribution to the above-mentioned topic, the practical importance nevertheless seems to be much larger. Namely, the constant public disclosure of facts and data in this field not only draws attention to this extremely important issue, but it also gives concrete ways to deal with the problem. This case study aimed to unite one part of these works, present them chronologically and tabularly and, based on their detailed analysis, make appropriate conclusions. The fact that in all, except in one work within this review, the researchers have come to the conclusion that physical activity has statistically significant positive effects on body composition of children, it is quite encouraging and gives an incentive to continue researching and conducting studies on this and similar topics.

\section{References}

Burguera B, Colom A, Piñero E, Yanez A, Caimari M, Tur J, Frontera M, Couce M, Cardo E, Aguiló A, Burguera A, Cabeza, E. ACTYBOSS: activity, behavioral therapy in young subjects--after-school intervention pilot project on obesity prevention. Obesity Facts, 2011; 4(5): 400-406.

Calcaterra V, Larizza D, Cadrons E, De Silvestri A, Brambilla P, Arpesella M, Vandoni M. J Pediatr Endocrinol Metab, 2013; 26(3-4): 271-276.

Clark JE. Motor development. In V. S. Ramachandran (Ed.) Encyclopedia of human behavior (Vol. 3, pp. 245255). San Diego: Academic Press, 1994. 
Evans R, Franco R, Sterm M, Wickham E, Bryan D, Herrick J, Larson N, Abell A, Laver J. Evaluation of a 6month multi-disciplinary healthy weight management program targeting urban, overweight adolescents: effects on physical fitness, physical activity, and blood lipid profiles. Int J Pediatr Obes, 2009; 4(3): 130-133.

Grave J, Andersen L. Enlightenment and measurement - a way to improve health among high school students. J Sports Sci, 2012; 30(12): 1199-1205.

Guo H, Schenkelberg MA, O'Neill JR, Dowda M, Pate RR. How does the relationship between motor skill performance and body mass index impact physical activity in preschool children? Pediatr Exerc Sci, 2018; 30(2): 266-272.

Hardy O, Wiecha J, Kim, Salas C, Briceno R, Moody K, Becker J, Glazer G, Ciccarelli C, Shi L, Hayman L. Effects of a multicomponent wellness intervention on dyslipidemia among overweight adolescents. J Pediatr Endocrinol, 2012; 25(1-2): 79-82.

Horvat V, Mišigoj-Duraković M, Prskalo I. Body Size and Body Composition Change Trends in Preschool Children over a Period of Five Years. Coll Antropol, 2009; 33(1): 99-103.

Jones MA, Skidmore P, Stoner L, Harrex H, Saeedi P, Black K, Gibbs BB. Associations of short bout sedentary behavior and physical activity with adiposity and fitness in children: 1895 Board\# 156 May 312 . Med Sci Sports Exerc, 2018; 50(5S): 454-455.

Jürimäe T, Jürimäe J. Growth, physical activity, and motor development in preburtal children. Boca Raton, FL: CRC Press, 2000.

Krebs NF, Jacobson MS, American Academy of Pediatrics Committee on Nutrition. Prevention of pediatric overweight and obesity. Pediatrics, 2003; 112(2): 424-430.

Lohman TG. Assessment of Body Composition in Children. Pediatr Exerc Sci, 1989; 1(1): 19-30.

Medved R. Sportska medicina. Zagreb: JUMENA, 1980.
Meucci M, Cook C, Curry C, Guidetti L, Scott R. World Journal Pediatric. 2013; 9(4): 307-311.

Pinhas-Hamiel O, Dolan LM, Daniels SR, Stadiford D, Khoury PR, Zeitler P. Increased incidence of noninsulin-dependent diabetes mellitus among adolescents. J Pediatr, 1996; 128(5): 608-615.

Sallis JF, Conway TL, Cain KL, Carlson JA, Frank LD, Kerr J, Glanz K, Chapman JE, Saelens BE. Neighborhood built environment and socioeconomic status in relation to physical activity, sedentary behavior, and weight status of adolescents. Prev Med, 2018; 110: $47-54$.

Szakály Zs. Testalkat, testösszetétel és motorikus teljesítményjellemzők vizsgálata. [Analysis of somatotype, body composition and motor abilities]. Doktorska disertacija, Budimpešta: Univerzitet Semmelweis, 2008.

Song J, Stebbins C, Kim T, Kim H, Kang H, Chai J. Effects of 12 weeks of aerobic exercise on body composition and vascular compliance in obese boys. J Sports Med Phys Fitness, 2012; 52(5): 522-529.

Simon C, Schweitzer M, Oujaa A, Arveiler T, Copin N, Blanc S, Platat C. Int J Obes. 2008; 32(1): 1489-1498.

Strauss RS. Childhood obesity and self-esteem. Pediatrics, 2000; 105(1): e15.

Tse M, Yuen D. Effects of providing a nutrition education program for teenagers: dietary and physical activity patterns. Nurs Health Sci, 2009; 11(2): 160-165.

Velez A, Golem D, Arent S. The impact of a 12-week resistance training program on strength, body composition, and self-concept of Hispanic adolescents. J Strength Cond Res, 2010; 24(4): 1065 1073.

World Health Organization. Global Strategy on Diet and Physical Activity. Geneva, Switzerland: World Health Organization, 2004. http://www.who.int/dietphysicalactivity/strategy/e b11344/strategy_english_web.pdf (accessed 08.06.2018.) 